\title{
Psikolojik Sermayenin İş Tatmini, Örgütsel Bağlılık ve Sinizm Üzerindeki Etkisi
}

\section{The Effects of Psychological Capital on Job Satisfaction, Organizational Commitment And Cynicism}

\author{
Cem Şen, ${ }^{a^{*}}$ İbrahim Sani Mert ${ }^{\mathrm{b}}$
}

${ }^{a}$ Dr., Millî Savunma Bakanlığı, Ankara/Türkiye.

ORCID: 0000-0002-7300-0170

b Prof. Dr., Antalya Bilim Üniversitesi, İktisadi, İdari ve Sosyal Bilimler Fakültesi, İșletme Bölümü, Antalya/Türkiye. ORCID: 0000-0002-2850-1865

\section{MAKALE BILGIISI}

\section{Makale Geçmişi:}

Başvuru tarihi: 15 Ağustos 2018

Düzeltme tarihi: 18 Ekim 2018

Kabul tarihi: 25 Aralık 2018

\section{Anahtar Kelimeler:}

Psikolojik Sermaye

İş Tatmini

Örgütsel Bağlılık

Sinizm

\section{ARTICLE INFO}

\section{Article history:}

Received 15 August 2018

Received in revised form 18 October 2018

Accepted 25 December 2018

\section{Keywords:}

Psychological Capital

Job Satisfaction

Organizational Commitment

Cynicism

\section{ÖZ}

Psikolojik sermaye son zamanlarda işletme yazınında üzerinde oldukça durulan bir değişken olmuştur. Yerli ve uluslararası yazında psikolojik sermayenin örgütsel sonuç değişkenleri ile olan etkileri inceleyen çalışmaların sayısı artmıştır. Yapılan bu çalışmada, psikolojik sermayenin iş tatmini, örgütsel bağlılık ve sinizm üzerindeki etkisi incelenmiştir. Yapılan araştırma nicel araştırma deseni kullanan, kesitsel bir alan araştırması olup, araştırma kapsamındaki veriler savunma sektöründe faaliyet gösteren üç farklı şirkette çalışan toplam 295 katılımcıdan elde edilmiştir. Araştırmadan elde edilen bulgulara göre psikolojik sermaye, araştırmanın bağımlı değişkenleri olan iş tatmini, örgütsel bağlılık ve sinizmi anlamlı olarak yordamaktadır.

\section{Giriş}

Günümüzde beyaz yakalı çalışanların oranı mavi yakalılara göre her geçen gün artmaktadır. Yaşanan hızlı teknolojik değişim ve gelişim, hangi sektörde olursa olsun iş yapma şeklini etkilemekte ve eğitim seviyesi yüksek beyaz yakalı çalışan sayısını artırmaktadır. Geçmişle kıyaslandığında eğitim seviyesi yüksek, çevresine duyarlı, farkındalığı artmış çalışanlar, çalıştıkları iş ve iş çevresine karşı daha hassas bir algı ve tutum içerisine girmişlerdir.
Diğer yandan, işveren veya örgütler açısından baktığımızda iş tatmini yüksek, çalıştığı örgütte uzun süre kalacak örgütsel bağlılığa sahip, aynı zamanda örgütün bir parçası ve takım elemanı olarak hareket edip olumsuz davranışlar sergilemeyen, değer odaklı bir çalışma ve etkileşim sergileyecek iş görenlere olan ihtiyaç artmıştır. $\mathrm{Bu}$ kapsamda, etkililik ve verimliliği arttıracak temel bazı örgütsel sonuç değişkenlerine verilen önem hem uygulayıcılar bazında hem de konu ile ilgili çalışan akademisyenler bazında artmıştır.

* Sorumlu yazar/Corresponding author

e-posta: cem.sen@hotmail.com 
Günümüzün yoğun hatta acımasız rekabet ortamında örgütlerin varlığını sürdürebilmeleri için çok uyumlu bir takım halinde çalışan, işinden yüksek tatmin duyan, sadakati yüksek çalışanlar ön plana çıkmıştır. Bu nedenle, örgütün başarısı açısından önemli bir yere sahip olan bahse konu örgütsel değişkenlerin üzerinde etkili olan öncül değişkenlerin belirlenmesi, örgütsel başarı açısından önemli bir arayış haline gelmiştir. Bu kapsamda, son yıllarda ön plana çıkan önemli bir örgütsel öncül değişken psikolojik sermayedir. Çalışanın zor ve meşakkatli işleri başarabilmesi, şimdiye ve geleceğe yönelik başarılı olacağına ilişkin olumlu bir beklenti içinde olması, umudunu kaybetmeden kişisel ve örgütsel hedeflere ulaşmada azim ve kararlı olması diğer bir ifadeyle yüksek bir psikolojik sermayeye sahip olması kritik bir hususa haline gelmiştir.

Psikolojik sermaye bu önemine binaen, birçok araştırmaya konu olmaya başlamıştır. Uluslararası yazında psikolojik sermayenin örgütsel farklı sonuç değişkenlerine olan etkilerini inceleyen birçok çalışma yapılmıştır (Örn., Luthans, Avolio, Avey ve Norman, 2007; Luthans, Norman, Avolio ve Avey, 2008a; Shahnawaz ve Jafri, 2009; Vazquez, Hervas, Rahona ve Gomez, 2009; McMurray, Pirola-Merlo, Sarros ve Islam, 2010; Peterson, Luthans, Avolio, Walumbwa ve Zhang, 2011; Shabir, Abrar, Baig ve Javed, 2014; Qadeer ve Jaffery, 2014).

$\mathrm{Bu}$ kapsamda, yapılan bu çalışmada psikolojik sermayenin iş tatmini, örgütsel bağlıllı ve sinizm üzerindeki etkisi araştırılmaya çalışılmıştır. Çalışma nezdinde oluşturulan araştırma soruları aşağıda sıralanmıştır:

- Çalışanların psikolojik sermayeleri, iş tatminlerini nasil etkilemektedir?

- Çalışanların psikolojik sermayeleri, örgütsel bağlılıklarını nasıl etkilemektedir?

- Çalışanların psikolojik sermayeleri, sinizmi nasıl etkilemektedir?

Araştırmanın bundan sonraki bölümlerinde ilk olarak psikolojik sermayenin ve psikolojik sermayenin çalışanın, araştırmanın bağımlı değişkenleri olan iş tatmini, örgütsel bağlılık ve sinizm ile olan ilișkisine yönelik yazın incelemesine yer verilmiş, müteakiben yöntem kısmında, araştırmanın evren ve örneklemi, kullanılan ölçekler, yapılan analizler ve araştırma bulgularına değinilmiştir. Son olarak sonuç ve çıkarımlar kısmında ise elde edilen bulgular, uygulayıcılar ve bundan sonra yapılan yapılacak çalışmalara da 1şık tutacak şekilde tartışılmıştır.

\section{Teorik Arka Plan}

\subsection{Psikolojik Sermaye}

Psikolojik sermaye son zamanlarda üzerinde fazlaca durulan bir değişken olmuştur. Bunun en önemli sebebi, psikolojik sermayenin geleneksel, entelektüel ve sosyal sermaye ile birlikte beşeri sermayenin gücünü artırabileceği noktasında kendisini göstermesidir.

Akçay (2011) da psikolojik sermayenin katkısını verimliliği artıran, yapılan işin kalitesini yükselten ve beşeri sermayeyi açıklayan bir diğer önemli etken olarak, o örgütte bulunan pozitif örgütsel davranışı öne çıkarmaktadır. Bu bağlamda geleneksel olarak rekabet avantajı yaratan kaynaklar ile psikolojik sermayenin bileșenleri ile kabul gören önemli kriterler kapsamında karşılaştırıldığı bilgiler Luthans ve Youssef (2004)'den uyarlanarak Tablo 1'de sunulmuştur.

Tablo 1. Rekabet Avantajı Yaratan Çeşitli Kaynakların Durumu

\begin{tabular}{|c|c|c|c|c|c|c|}
\hline \multicolumn{2}{|c|}{ Kaynaklar } & $\begin{array}{c}\text { Uzun } \\
\text { vadeli } \\
\text { mi? }\end{array}$ & $\begin{array}{c}\text { Eşsiz } \\
\text { mi? }\end{array}$ & $\begin{array}{l}\text { Biriktirile- } \\
\text { bilir mi? }\end{array}$ & $\begin{array}{c}\text { Birbirine } \\
\text { bağlı } \\
\text { mı? }\end{array}$ & $\begin{array}{l}\text { Yenilene- } \\
\text { bilir mi? }\end{array}$ \\
\hline \multirow{3}{*}{$\begin{array}{l}\text { Geleneksel } \\
\text { Sermaye }\end{array}$} & Finansal & Hayır & Hayır & Evet & Hayır & Hayır \\
\hline & Yapısal/Fiziksel & Evet & Hayır & Evet & Belki & Belki \\
\hline & Teknolojik & Hayır & Hayır & Hayır & Belki & Hayır \\
\hline \multirow{2}{*}{$\begin{array}{l}\text { Beşeri } \\
\text { Sermaye }\end{array}$} & Açık Bilgi & Belki & Hayır & Evet & Hayır & Belki \\
\hline & Örtük Bilgi & Evet & Evet & Evet & Evet & Evet \\
\hline \multirow{3}{*}{$\begin{array}{l}\text { Sosyal } \\
\text { Sermaye }\end{array}$} & Sosyal Ağlar & Belki & Evet & Evet & Evet & Belki \\
\hline & Norm/Değerler & Evet & Evet & Evet & Evet & Evet \\
\hline & Güven & Evet & Evet & Evet & Evet & Evet \\
\hline \multirow{4}{*}{$\begin{array}{l}\text { Psikolojik } \\
\text { Sermaye }\end{array}$} & Öz Yeterlilik & Evet & Evet & Evet & Evet & Evet \\
\hline & İyimserlik & Evet & Evet & Evet & Evet & Evet \\
\hline & Umut & Evet & Evet & Evet & Evet & Evet \\
\hline & Psi.Day. & Evet & Evet & Evet & Evet & Evet \\
\hline
\end{tabular}

Tablo 1'de sunulan kriterlerin psikolojik sermaye tarafından tamamen karşılanması ve ona gösterilen ilgi; özellikle değerli, nadir, taklit ve ikamesi zor olan stratejik kaynaklar (Barca, 2005) ile örgütsel performans arasındaki pozitif ilişki kapsamında doğrulanmıştır (Newman vd., 2014). Sürdürülebilir rekabet avantajına katk1 sunan stratejik kaynaklar arasında beşeri sermaye, diğer tüm kaynaklar arasında evrensel olarak en değerli ve taklit edilmesi en zor kaynak olarak kabul edilmektedir (Wright vd., 2001; Crook vd., 2008). Bu bağlamda beşeri sermaye üzerindeki etkisinin tüm dikkatleri psikolojik sermaye üzerine topladığı (Ardichvili, 2011) ifade edilmektedir. Kaynağını pozitif psikoloji (Seligman ve Csikszentmihalyi, 2000) ve pozitif örgütsel davranış (Wright, 2003; Cameron, Dutton ve Quinn, 2003) konularından alan psikolojik sermaye Luthans ve çalışma arkadaşları (2004) tarafindan geliştirilmiştir. Söz konusu yaklaşımın, bugün ve geleceğin zorluklarını aşmak için kullanılmakta olan ortalama performans sağlayan (Avolio ve Luthans, 2006) ve bilinen yaklaşımlar yerine yeni yaklaşımlara duyulan ihtiyaçtan kaynaklandığı (Luthans vd., 2007a) ifade edilebilir.

Tarihsel olarak incelendiğinde örgütün verimliliğini geliştirmek üzere işgörenlerin, grupların ve yapıların örgüt içerisindeki davranışlara olan etkisini araştıran (Robbins ve Judge, 2012) örgütsel davranış alanındaki ilk çalışmanın Hawthorne Araştırması (Scott ve Davis, 2007) olduğu ifade edilebilir. Söz konusu çalışmada çalışanın pozitif duygu ve yaklaşımları ile performansı arasında ilk defa açık bir ilişkinin varlığından söz edilmiştir. Sonrasında yapılan diğer tüm çalışmalarda da pozitif etki ve davranışların performans üzerindeki olumlu etkileri ortaya konulmuş ve özellikle her seviyedeki kendine güvenen, mutlu ve iyimser çalışanın daha üretken olduğu gözlemlenmiştir (Stajkovic ve Luthans, 1998). Oysaki örgütsel davranış alanında bu tür pozitif yaklaşımlar yerine daha çok işyerindeki problemler ve işlev bozuklukları üzerinde durulmuştur; zaman içerisinde örgütsel davranış alanı ile ilgilenen akademik çevre, yavaş yavaş ilgisini çalışanın zayıf yönleri yerine 
güçlü yönlerine yönelterek "pozitif örgütsel davranış konseptini”” öne çıkarmıştır (Luthans, 2002b).

Bugüne kadarki yaklaşımların bireylerin ve örgütlerin pozitif ve güçlü yönlerine yeterince ilgi göstermek yerine (Luthans, 2002b), neden negatif ya da yanlış giden konuları ile ilgilendiğine (Seligman, Parks ve Steen, 2004; Sheldon ve King, 2001; Wright, 2003) gelince, Gable ve Haidt (2005) zaaf ve kusurlarla ilgilenmenin nedenini üç madde ile özetlemiştir:

- Problem yaşayanlara yardım etme tutkusu: Bireylerin güçlü yönleri ile ilgilenmek yerine ihtiyacı olanların zaaf ve kusurları, stresi ve hastalıkları ile başa çıkmasına yardımı tercih eden bir anlayışa sahip olunmasıdır. Zira acı çekenlere öncelikle yardım edilmesi etik olarak daha doğru olarak algilanmaktadır.

- Tarihi Sebepler: II. Dünya Savaşı sonrasında psikologlar tarafindan kurulan araştırma merkezlerinin çalışmalarında önceliklerini eve dönen gazilerin psikolojik ve diğer problemleri üzerine yoğunlaşmalarıdır. Ayrıca, tıbbi bir hastalık modeli kapsamında ele alınan psikolojik sorunlar ve bunların tedavisi için uygulanan terapiler oldukça maliyetli olduğundan, söz konusu tedaviler için ayrılan ödeneklerin sağlıklı insanlar için harcanması doğru bulunmamaktadır.

- Psikologların doğasından ve psikolojik süreçlerle ilgili teorilerden kaynaklanan sebepler: Kötü, negatif veya zayıf yönlerle ilgilenmek; iyi, pozitif veya güçlü yönler ile ilgilenmekten daha baskın bir tutum olup, onları tedavi etmeye çalışmak daha tatminkâr olmaktadır. Yazında kötü şeyler hakkındaki araştırmaların iyi şeylere oranla daha derin etkilere sahip olduğu ortaya konulmuştur.

Bireylerin güçlü taraflarına yeterince vurgu yapılmadığını ilk fark edenlerden birisi Martin E.P. Seligman olmuştur (Seligman ve Csikszentmihalyi, 2000). Seligman, başlattığı proaktif pozitif yaklaşım ile hayattaki kötü şeylere olan ilgiyi iyi şeylere yöneltmiş (Luthans, 2002b), psikolojik bulgulardan yola çıkarak insanlara daha mutlu, daha başarılı ve daha iyimser olabileceklerini öğretmek için "pozitif psikoloji" kavramını kullanmanın gerekliliğini vurgulamıştır (Compton, 2005; Kauffman, 2006; Kobau, Seligman, Peterson, Zack, Chapman ve Thompson, 2011; Linley, Joseph, Harrington ve Wood, 2006). Böylece iş yaşamında, çalışan davranışlarının yalnızca olumsuz taraflarına odaklanılması yerine, farklı bir bakış açısı ile daha çok olumlu taraflarına odaklanılarak, iş ortamının problemlerin yanında, çözüm ve başarıları da içerdiği ortaya konulmaya çalışılmıştır.

Psikolojik sermayenin gelişimi, pozitif psikolojinin şemsiyesi altındaki pozitif örgütsel davranışın (Bakker ve Schaufeli, 2008; Cameron, 2005; Donaldson ve Ko, 2010) en önemli katkılarından birisi olarak ifade edilebilir. Pozitif örgütsel davranış, çalışma hayatında performansın iyileştirilmesi için ölçülebilir, geliştirilebilir ve etkili bir şekilde yönetilebilir pozitif eğilimli insan kaynaklarının güçlü yönleri ve psikolojik kapasiteleri hakkındaki çalışma ve uygulamaları olarak tanımlanmıştır (Avey vd., 2010; Donaldson ve Ko, 2010; Gygax, Ticino ve Fitzgerald, 2011;
Luthans, 2002b; Luthans vd., 2007a). Söz konusu tanımda yer alan psikolojik kapasitelerin; kuram ve araştırma temelli, geçerli ölçüm araçları, duruma özgü (state-like) veya gelişime açık ve performans etkisi kriterlerini içermesi (Luthans vd., 2007a) gerektiği ifade edilmektedir. Duruma özgü olma özelliği, pozitif örgütsel davranış kapasitesinin değişime, gelişime açık ve kolayca uyum sağlayabildiğini (Avolio ve Luthans, 2006) vurgulamaktadır.

Pozitif örgütsel davranış, işgörenlerin sergileyebileceği olumsuz tutum ve davranışlara engel olabilmenin bir yolu (Avey, Hughes, Norman ve Luthans, 2008) olarak görülmektedir. Bu düşüncenin altında geleceğe yönelik pozitif beklentileri olan işgörenlerin daha olumlu, negatif beklentileri olanların ise daha olumsuz bir bakış açısına sahip olmalarından kaynaklanmaktadır (Wanous, Reichers ve Austin, 2000). Bu bağlamda pozitif örgütsel davranışın öneminin, söz konusu olumsuzlukların aşılmasında sağlayabileceği katkı ile doğru orantılı olduğu vurgulanabilir.

Pozitif örgütsel davranış köklerini pozitif psikolojideki teori ve araştırmalardan almaktadır (Çetin ve Basım, 2012). Pozitif psikoloji kavramı ilk defa Maslow tarafından 1954 yılında "Motivasyon ve Kişilik" adı ile yayımlanan kitapta kullanılmıştır (Compton, 2005; Froh, 2004; Hefferon ve Boniwell, 2011; Wright, 2003). Söz konusu kitapta Maslow (1954), psikoloji biliminin bireyin negatif taraflarına ilişkin yapılan araştırmalarda pozitif taraflarına ilişkin olanlara göre daha başarılı olduğunu, insanoğlunun zayıf ve patolojik durumlarını açığa çıkarırken onun güçlü ve başarı potansiyeline ilişkin çok az şey yaptığını belirtmekte ve bu nedenle de ilgisini pozitif tarafa çevirmesinin zamanının geldiğini vurgulamaktadır. Başlangıcı Maslow'a kadar uzanan pozitif psikoloji, bireylerin yaşam kalitesini geliştirmek, yaşamın onlar için anlamsız gelmeye başladığında meydana gelebilecek patolojik rahatsızlıkları önlemek amacıyla pozitif öznel deneyimleri, pozitif kişilik özelliklerini ve örgütleri inceleyen bir bilim olarak tanımlanmaktadır (Seligman ve Csikszentmihalyi, 2000). Seligman'ın vurguladığı pozitif psikoloji ile Maslow tarafından tanımlanan pozitif psikoloji arasında büyük oranda benzerlik bulunmaktadır (Wright, 2003).

\subsection{Psikolojik Sermaye ve İş Tatmini}

Kişilerin yaşamlarının büyük bir bölümünü geçirdikleri işlerinde mutlu olmaları, hem kişisel hem de örgütsel açıdan önem taşımakta (Rode, 2004; Youssef, 1998) ve bu durum önemli sonuçlara sebep olmaktadır (Ensher, GrantVallone ve Donaldson, 2001). Kuramsal temellerini temel motivasyon teorilerinden alan iş tatmini hakkında yazında birçok tanım yapılmıştır. $\mathrm{Bu}$ bağlamda yapılan tanımlara göre, iş tatmini;

- Çalışanın, işinin özellikleri ile ilgili yaptığı değerlendirme sonucunda işi ile ilgili olumlu bir duyguya/tavra sahip olması (Babin ve Griffin, 1998; Colquitt, Lepine ve Wesson, 2015; Robbins ve Judge, 2012; Vroom, 1964) ve bu nedenle de mutluluk duyması (Hackman ve Oldham, 1975),

- Kişinin, çalışma yaşamındaki tecrübelerinden kaynaklanan memnuniyet duygusu ve kişinin işine karşı almış olduğu pozitif bir tutum (Greenberg ve Baron, 2000; Locke, 1976; Özcan, 2011) veya söz 
konusu kiși ile iş yeri arasındaki uyumu (Judge, Hulin ve Dalal, 2009; Ugboro ve Obeng, 2000),

- Çalışanın işinin farklı yönlerine karşı güttükleri tutumların tamamı (Schultz ve Schultz, 1990),

- Bireyin yaptı̆̆ı iş hakkındaki genel tavrı (Sı̆̆rı ve Basım, 2006) olarak tanımlanabilir.

İş tatmini kavramının ortaya konulmasında motivasyon teorilerinden yararlanıldığ bireylerin ne şekilde motive edildiğine odaklanan içerik kuramları ile durağan çevre koşulları varsayımından hareket ederek iş motivasyonunun dinamik bir süreç içerisinde gerçekleştiğini savunan süreç kuramlarından oluşmaktadır (Paşamehmetoğlu ve Yeloğlu, 2013). Motivasyon ile iş tatmini birlikte ele alındığında her iki kavramın da kişisel olarak duygusal ve öznel özellikleri birlikte barındırdığı, bu bağlamda işgörenin motive edilmesi sonrasında sergileyeceği davranışlar ile iş tatmini arasında yakın bir ilişki olduğu ifade edilmektedir (Çetin, 2011). İşinden tatmin olan bir işgörenin motive edilebilmesi için uygun koşulların sağlandığı, bu durumun da örgüt açısından verimlilik anlamına geldiği söylenebilir. Aslında iş tatmininin akademik yazında yer almasının büyük oranda nedeni, verimliliğin artırılmasına katkısının araştırılmasına yönelik olmasındandır (Agho vd., 1992). İş tatmini kısaca kişi-çevre uyumu (Kristof-Brown, Zimmerman ve Johnson, 2005) olarak da düşünülebilir.

İnsan aktif yaşamının büyük bir bölümünün iş yerinde geçtiği göz önünde bulundurulduğunda; işgörenin işindeki mutluluğunun (yüksek iş tatmininin) yaşamını büyük ölçüde etkilediği, bunun kendi ruhsal ve bedensel sağlığ üzerinde olumlu etki gösterdiği, dolayısıyla aile yaşamındaki mutluluğunu ve örgütteki verimliliğini artırdığı kolaylıkla tespit edilebilir (Çelik vd., 2014; Örücü vd., 2006). İş tatminini etkileyen faktörler olarak;

- Örgütsel faktörler (ücret, yükselme firsatları, işin doğası ve niteliği, örgütlerin politika ve prosedürleri ile çalışma şartları),

- Grup faktörleri (çalışma arkadaşları ile yöneticilerin tutum ve davranış şekilleri),

- Bireysel faktörler (kişinin statü ve pozisyon gibi ihtiyaç ve beklentileri),

- Kültürel faktörler (bireyin sahip olduğu inanç, değer ve tutumları) ve

- Çevresel faktörleri (bireyi etkileyen sosyal, ekonomik ve devlete ait tüm faktörleri) siralayabiliriz (Örücü vd., 2006; Schultz ve Schultz, 1990).

Yapılan birçok araştırma sonucunda; eksikliğinde iş devamsızlığı, işten ayrılma niyetinin ortaya çıkması, örgütsel bağlılıkta azalma, stres, üretim karşıtı davranışların ve verimsizliğin artmasına sebep olan (Gürbüz ve Sı̆̆rı, 2013; Robbins ve Judge, 2012) iş tatmini ile;

- Algılanan örgütsel destek arasında pozitif yönde (Gutierrez vd., 2012; Huang, Shawaand ve Chen, 2004; Saekoo, 2011; Yoon ve Thye, 2002),

- Algilanan örgütsel adalet arasında pozitif yönde (Colquitt vd., 2001; Moorman, Blakely ve Niehoff, 1998; Vitell ve Singhapakdi, 2008),

- Öz kendilik değerlendirmesi arasında pozitif yönde (Bono ve Judge, 2003; Judge vd., 1997; 1998),
- Psikolojik sermaye arasında pozitif yönde bir ilișki olduğu (Chandrasekar ve Chidambaram, 2015; Çetin, 2011a; Goldsmith, Veum ve Darity, 1997; Judge ve Llies, 2004; Larson ve Luthans, 2006; Youssef ve Luthans, 2007; Luthans vd., 2007b; Turner vd., 2002; Watson, 2002) ortaya konulmaya çalışılmıştır.

\subsection{Psikolojik Sermaye ve Örgütsel Bağl1lık}

İşgören ile çalıştığı örgüt arasındaki uyumun en önemli göstergelerinden biri olan örgütsel bağl1lık, bütün örgütler için büyük önem taşımaktadır. Söz konusu önem, örgütsel bağlılığın temelinde işgörenlerin, örgütlerinin başarılı olması ve belirlediği hedeflere ulaşmasında çaba sarf etme isteklerini içermesindendir (Çetin ve Basım, 2011; Steers, 1981). Bu bağlamda örgütsel bağlılık;

- Bir çalışanın örgütüne ve onun amaçlarına bağlı olma, kendini söz konusu amaçlar ile özdeşleştirme ve onun üyesi olarak devam etme isteğinin derecesi (Colquitt vd., 2015; Robbins ve Judge, 2012; Steers, 1981),

- İşgörenlerin kimliklerini örgütleriyle özdeşleştirmelerinin yanında, örgüte yönelik geliştirdikleri tutum ve yönelişleri (Sheldon, 1971),

- Kişilerin örgüt özelliklerini içselleştirme ve bu bağlamda örgüte ve onun değerlerine uyum gösterme derecesi (Grusky, 1966; McDonald ve Makin, 2000),

- Örgüt ile işgören arasındaki ilişkiyi tanımlayan, bireyin örgütte çalışmaya devam etmesine neden olan, kişinin psikolojik hali (Meyer ve Allen, 1997) olarak tanımlanabilir.

Her ne kadar farklı farklı tanımlar yapılsa da örgütsel bağlılığı yüksek çalışanların ortak özellikler taşıdıkları, bunların da; örgütün hedef ve değerlerini içselleştirme, örgütsel role bağlanma, uzun yıllar örgüt içinde kalma arzusu ve örgütün hedef ve amaçları doğrultusunda gayret gösterme isteği olduğu ifade edilmektedir (DeCotiis ve Summers, 1987).

Örgütsel bağlılık çok farklı şekillerde sınıflandırılarak daha iyi anlaşılmaya çalışılmıştır (Örn., Etzioni, 1961; Kanter, 1968; Katz ve Kahn, 1966). Ancak yönetim ve örgüt yazınında en çok kabul görmüş olan sınıflandırma Allen ve Meyer (1990) tarafindan yapılan sınıflandırmadır. Onlara göre örgütsel bağlılığın üç farklı boyutu bulunmaktadır (Allen ve Meyer, 1990; Meyer ve Allen, 1991; Meyer, Stanley, Herscovitch ve Topolnytsky, 2002) ve bunlar;

- Bireylerin örgütlerine duygusal bağlılığı ve onların değerlerine inanmalarını ifade eden duygusal bağlılık: Örgüte karşı duyulan güçlü duygusal bağl1lığı olan çalışanlar; örgüt ile bütünleşmekte, örgüt amaçları ile özdeşleşmekte, örgüte daha faydalı olmak için daha fazla hevese sahip olmakta ve bu nedenle de örgüt üyeliklerini devam ettirmektedirler.

- Örgütten ayrılmanın getireceği maliyetlerin farkında olmak anlamına gelen devam bağlılı̆̆ı/zorunlu bağlılık: $\mathrm{Bu}$ bağlılı̆̆ın gelişmesinde, işgörenlerin örgüt içerisinde yaptıkları yatırımlar ile başka iş 
alternatiflerinin olmadığı yönündeki algılamaları önemli bir rol oynamaktadır.

- Çalışanın örgütüne bağlılığı, ahlaki ya da etik nedenlerden dolayı bağlılık göstermesini bir görev olarak algılaması ve örgüte bağlılığın doğru olduğunu düşünmesini sağlayan normatif/ahlaki bağlılık: Örgüte karşı normatif bağlılığa sahip çalışanlar; sorumluluk duyguları ile örgüte bağlanmakta, böyle olması gerektiği ve bu şekilde davranmaya zorunlu olduklarını hissettikleri için örgütte kalmaya devam etmektedirler.

Wasti'ye (1999) göre; duygusal bağlılık kişiler istedikleri için, devam bağlılığı çıkarlar bağlanmayı gerektirdiği için ve normatif bağlılık ise ahlaki gerekçelerle ortaya çıkmaktadır. Yapılan birçok araştırma sonucunda; eksikliğinde iş devamsızlığı, işten ayrılma niyetinin ortaya çıkması, stres ve verimsizliğinin artmasına sebep olan (Becker, Billings, Eveleth ve Gilbert, 1996; Mowday, Porter ve Steers, 1982; Robbins ve Judge, 2012) örgütsel bağlilık ile;

- Algılanan örgütsel destek arasında pozitif yönde (Eisenberger vd., 1990; Kaplan ve Öğüt, 2012; Nayir, 2012; Nitesh vd., 2013),

- Algılanan örgütsel adalet arasında pozitif yönde (Folger ve Cropanzano, 1998; Irving vd., 2005; Totawar ve Nambudiri, 2014),

- Öz kendilik değerlendirmesi arasında pozitif yönde (Bowling vd., 2012; Kittinger vd., 2009),

- Psikolojik sermaye arasında pozitif yönde bir ilişki olduğu (Çetin, 2011a; Etebarian vd., 2012; Larson ve Luthans, 2006; Youssef ve Luthans, 2007) ortaya konulmuştur.

\subsection{Psikolojik Sermaye ve Sinizm}

Sinizm, son yıllarda adından çokça söz ettirmeye başlayan örgütsel davranış sonuç değişkenlerinden birisi olarak karşımıza çıkmaktadır. Bu ilginin altında sinizmin örgütler için zararlı bir çalışan tutumu olarak görülmesi, etkinlik ve etkililiklerinin azalmasının temel nedenlerinden biri olarak sayılması yatmaktadır. Bir başka ifadeyle sinizm, örgütlerin başarısını engelleyen önemli bir tehdit unsuru olarak karşımıza çıkmaktadır. Sosyal bilimlerin birçok kavramında rastlanıldığ gibi üzerinde bilim insanlarının uzlaştığı bir sinizm tanımı bulunmamaktadır (Cole, Bruch ve Vogel, 2006). Bu bağlamda yapılmış bazı tanımlara göre sinizm;

- Başkalarına düşmanca tavır sergileme, onları sevmeme ve onlara güvenmeme özelliği (Barefoot, Dodge, Peterson, Dahlstrom ve Williams, 1989; Brandes vd., 2008; Cook ve Medley, 1954),

- Açık olunmaması nedeniyle ya da bağdaşmaz çelişkilerden kaynaklanan hissedilen belirsizlik ve hayal kırıklığı duygusu (Meyerson, 1990),

- Diğer bireylerin bencil, güvenilmez ve sadakat yoksunu olduklarına dair beslenen olumsuz kanaatler (Brandes, 1997),

- Bireylerin genel olarak karar ve eylemlerine yönelik açık ya da gizil olarak ortaya çıkan inançsızlık (Stanley, Meyer ve Topolnytsky, 2005),

- Bireylerin kişisel çıkarları söz konusu olduğunda dürüstlük, adalet ve samimiyet ilkelerini hiçe sayması (James, 2005),
- Diğer bireylerin iyi niyetinden șüphe duyularak genellenmesi ile ilgili diğer durumlara inanılırlık açısından yansitılmasıdır (Tan ve Tan, 2007).

Yapılan tanımlardan anlaşıldığı üzere sinizm, bireylerin sadece kendi menfaatlerini gözetmeleri, bu nedenle de herkesi çıkarcı ve güvenilmez kabul etmeleri neticesinde diğer bireylere olumsuz düşünceler beslemeleridir. $\mathrm{Bu}$ kapsamda örgütsel sinizm de bireyin içerisinde yer aldığı örgüte yönelik taşıdığı ve hissettiği olumsuz tutumlardır (Bedeian, 2007; Dean, Brandes ve Dharwadkar, 1998; Wilkerson, Evans ve Davis, 2008). Yapılan araştırmalar, örgütsel sinizmin bilişsel, duyuşsal ve davranışsal öğeler içeren, belirli ve büyük bir güce dayanan olumsuz bir tutum (Andersson, 1996; Andersson ve Bateman, 1997; Dean vd., 1998) olduğunu ortaya çıkarmıştır.

Örgütsel sinizmin bilişsel boyutuna göre işgörenler; örgütlerinin adalet, dürüstlük ve bütünlükten yoksun olarak uygulamalarıyla kendilerine ihanet ettikleri inancını taşımaktadır (Özgener, Ögüt ve Kaplan, 2008). Bu boyut, örgütlerdeki uygulamaların ilkelere dayalı olmadığı, resmi bildirgelerin işgörenler tarafından ciddiye alınmadığı, birey davranışlarının yalana dayandığı, kişisel çıkarların ön planda tutulduğu, tüm ahlaki ve etik uygulamaların çıkarlar uğruna feda edildiği ve bu nedenle de güvenilmez bir nitelik gösterdiği gibi inançları öne çıkarmaktadır (Brandes, 1997; Dean vd., 1998). Duyuşsal boyut, örgüte duyulan küçümseme, saygısızlık, üzüntü, sıkıntı, öfke, bıkkınlık ve utanç duyma gibi güçlü duygusal tepkileri içermektedir (Abraham, 2000; Dean vd., 1998). Temel olarak işgörenler tarafindan algılanan duygusal tecrübelerden oluşmaktadır. Söz konusu tecrübe edilen duygular işgörenin işine ve örgütüne karşı olan düşüncelerini şekillendirmektedir. Davranışsal boyut ise örgütü aşağılayan, küçük düşürmeye çalışan, sert eleştiri, alaycı yorum ve karamsar tahminleri içermektedir (Brandes ve Das, 2006; Dean vd., 1998). Bu boyut, işgörenin işine ve örgütüne karşı negatif davranışlar sergilemesini ifade etmektedir.

Sinizmin ortaya çıkmasında bireysel nedenler olarak yaş, cinsiyet, medeni durum, eğitim düzeyi (Mirvis ve Kanter, 1991) ve çalışma süresi (James 2005) gibi demografik değişkenlerin etkili olduğu; örgütsel nedenler olarak ise işgören ile örgüt arasında var olduğuna inanılan psikolojik sözleşme ihlalleri (Abraham, 2000; Andersson, 1996), örgütsel destek algısının düşük olması (Fleming, 2005), örgütsel adaletsizlik (Özgener vd., 2008), klasik iş yöntemleri ve değerleri, çok uzun çalışma süreleri, mobbing ve kötü yönetimi içeren örgütsel politikalar (Cartwright ve Holmes, 2006; Davis ve Gardner, 2004), etkin olmayan liderlik ve işgörenlere saygı duyulmaması (Cole vd., 2006), örgütsel küçülme, yeniden yapılanma ve işgörenlerin işten çıkarılması (Abraham 2000; Andersson, 1996), düşük örgütsel performans (Andersson ve Bateman, 1997) ve başarısız örgütsel değişim girişimleri (Ferres ve Connel, 2004; Wanous vd., 2000) gibi bilişsel, duygusal ve örgütsel birçok faktör yer almaktadır.

Sinizm düzeyleri yüksek işgörenlerin; örgütsel bağlılıklarında azalma, işe yabancılaşmaları, işe devamsızlık ve işten ayrılma niyetlerinde bir artış (Abraham, 2000; Dean vd., 1998), algılanan örgütsel desteklerinde azalma (Byrne ve Hochwarter, 2008), haksız muameleye uğradıkları düşüncesi ile yönetime olan 
güvensizliklerinde bir artış (Eaton, 2000), yaratıcılık ve üretkenliklerinde azalma (Kanter ve Mirvis, 1989) ve morallerinde düşüklük (Premeaux ve Mondy, 1986) olduğu tespit edilmiştir.

Yapılan araştırmalar sonucunda örgütsel düzeyde verimsizliğe neden olan sinizm ile;

- Algılanan örgütsel destek arasında negatif yönde (Brandes, 1997; Brandes, Das ve Hadeni, 2006; Byrne ve Hochwarter, 2008; George vd., 1993; James, 2005; Naus, 2007),

- Algılanan örgütsel adalet arasında negatif yönde (Bernerth, Armenakis, Feild ve Walker, 2007; Bommer vd., 2005; James, 2005),

- Öz kendilik değerlendirmesi arasında negatif yönde (Andersson, 1996; Judge, Locke, Durham ve Kluger,1998; Scott ve Zweig, 2008),

- Psikolojik sermaye arasında negatif yönde bir ilişki olduğu ortaya konulmuştur (Avey vd., 2008; Avey, Luthans ve Youssef, 2008a; Avey vd., 2008b; Avey, Luthans ve Youssef, 2010). Bu bağlamda, psikolojik sermayesi yüksek olan işgörenlerin sahip olduğu pozitif duygu, düşünce ve davranışların, örgütsel sinizmi ve etkilerini azaltabileceği ifade edilebilir.

\section{Yöntem}

\subsection{Araştırma Modeli ve Hipotezler}

Araştırma modeli Şekil 1'de sunulan yapıda kurgulanmıştır. Model temel olarak dört ana değişkenden oluşmaktadır. Bunlar; psikolojik sermaye ve psikolojik sermayenin etkilediği iddia edilen temel örgütsel sonuç değişkenlerinden iş tatmini, örgütsel bağlllık ve sinizm değişkenlerden oluşmaktadır.

Şekil 1. Araştırma Modeli ve Hipotezler

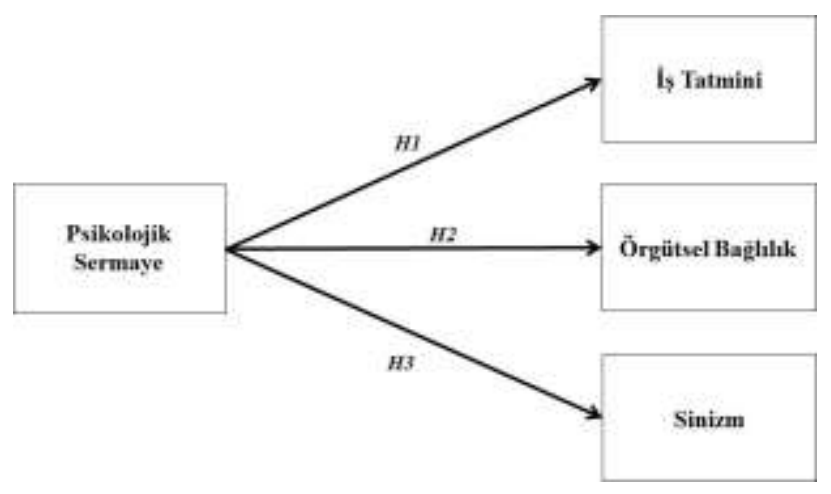

Araştırmanın yazınla ilgili bölümünü oluşturan teorik arka plan çerçevesinde giriş kısmında yer alan araştırma sorularını cevaplamak üzere aşağıdaki hipotezler geliştirilmiştir:

Hipotez 1: Çalışanların psikolojik sermayelerinin iş tatminleri üzerinde anlaml ve olumlu yönde etkisi vardır.

Hipotez 2: Çalışanların psikolojik sermayelerinin örgütsel bağlllıklarl üzerinde anlamlı ve olumlu yönde etkisi vardır.

Hipotez 3: Çalışanların psikolojik sermayelerinin sinizm üzerinde anlamlı ve olumsuz yönde etkisi vardır.

\subsection{Araştırmanın Uygulanması, Evren ve Örneklem}

$\mathrm{Bu}$ araştırmanın evrenini, savunma sanayinde faaliyet gösteren üç şirkette çalışan beyaz yakalı çalışanlar oluşturmaktadır. Bu kapsamda, araştırma evreninde toplam üç şirkette çalışan 980 beyaz yakalı çalışan mevcuttur. Araştırmada, örneklemi oluşturan personelden anket yöntemi ile toplanan veriler kullanılmıştır. Toplam 400 adet anket formu üç şirkete sahip oldukları beyaz yakalı çalışan oranlarına göre kolayda örneklem yöntemi kullanılarak dağıtılmış olup 309 anket geri toplanabilmiştir. Buna göre geri dönüşüm oranı \%77'dir. Geri dönüş yapmayan anketlerin araştırma sonuçlarını etkilemeyecek farklı nedenlerden kaynaklandığ 1 tespit edilmiştir. Toplanan 309 anketten 14 tanesi araştırmada kullanılmaya elverişli olmadığından, geriye kalan 295 anket araştırma kapsamında kullanılmıştır. Seçilen örneklem sayısının 0,95 güvenirlik ve 0,05 örneklem hatası kapsamında evren büyüklügünü temsil edilebileceği değerlendirilmektedir (Sekaran, 2003, s.294).

Araştırmaya katılanların \% 29.5'i (87 kişi) kadın, \% 70.5'i (208 kişi) erkek olup yaş ortalaması 34.3'tür. Katılımcıların hepsi üniversite mezunu olup \% 37.6's1 lisansüstü eğitim görmüştür.

\section{Bulgular}

4.1. Araştırma Kapsamında kullanılan Ölçeklerin Güvenilirliği ve Geçerliliği

\subsubsection{Psikolojik Sermaye Ölçeği (PSÖ)}

Çalışanların psikolojik sermaye seviyeleri Luthans ve arkadaşları (2007) tarafından geliştirilmiş olan psikolojik sermaye ölçeğinin Türkçe'ye uyarlanması ve geçerlemesi Çetin ve Basım (2012) tarafından yapılmıştır. Ulusal çalışmalarda ölçeğin geçerliliği ve güvenilirliğinin sağlandığı görülmektedir (Çetin, 2011a; Çetin, Hazır ve Basım, 2013; Tüzün, Çetin ve Basım, 2014). Ölçek 24 sorudan oluşmakta ve ölçeği oluşturan boyutlar öz yeterlilik (6 madde), iyimserlik (6 madde), umut (6 madde) ve psikolojik dayanıklılık (6 madde) şeklinde belirtilmektedir. Söz konusu alt boyutlar, her ne kadar birbirlerinden kavramsal olarak bağımsız olsa da; aynı zamanda tek bir kuramsal üst yapı olarak psikolojik sermayeye işaret etmektedir (Luthans vd., 2007; 2007a). Bu bağlamda analizlerde, psikolojik sermaye ölçeğinin tek tek boyutsal etkileri yerine, söz konusu üst yapının çalışanların içerisinde bulundukları psikolojik durumu öne çıkararak, sinerjik etkisini görmek amacıyla tüm boyutlarının toptan etkisi (ikincil seviyesi) ele alınmıştır. PSÖ, 5'li Likert tipinde hazırlanmış olup; "İşimde birçok şeyleri halledebileceğimi hissediyorum", "İşimle ilgili şeylerin daima iyi tarafını görürüm" gibi çeşitli yargı ifadeleri bulunmaktadır. Ölçekteki 1 'inci (" $\mathrm{Bu}$ iş yerinde, işler asla benim istediğim şekilde yürümez”), 8'inci ("İşimde bir terslikle karşılaştığımda, onu atlatma konusunda sıkıntı yaşıyorum") ve 11'inci ("Eğer işimde bir şeyler benim için yanlış gidecekse, o şekilde gider") maddeler ters kodlamıştır. Ölçeğe ait doğrulayıcı Faktör Analizi (DFA) sonuçları Tablo 2'dedir. Bu araştırmada söz konusu ölçeğin güvenilirliği Cronbach Alfa'sı 0,873 olarak bulunmuştur. 


\subsection{2. İ̧̧ Tatmini Ölçeği (İTÖ)}

Hackman ve Oldham (1975) tarafindan geliştirilen ve Basım ve Şeşen (2009) tarafından Türkçe'ye uyarlanarak geçerlemesi yapılan İş Tatmini Ölçeği (İTÖ), toplam beş sorudan oluşmakta ve bireyin genel iş tatminini tek boyut altında ölçmektedir. Ölçek "İşim benim için bir hobi gibidir", "İşimde, diğer birçok insandan daha mutlu olduğumu düşünüyorum", "İşimden çok keyif alıyorum" gibi yarg1 cümlelerinden oluşmaktadır. Ankete katılanlardan bu yargı cümlelerine hangi oranda katıldıklarını 5'li Likert tipi ölçek üzerinde işaretlemeleri istenmiştir. DFA sonuçları Tablo 2'dedir. Ölçeğin güvenilirliği Cronbach Alfa’sı 0,859 olarak bulunmuştur.

\subsection{3. Örgütsel Bağglllık Ölçeği (ÖBÖ)}

Örgütsel Bağlılık Ölçeği (ÖBÖ) olarak ise Jaworski ve Kohli (1993) tarafından geliştirilen ve Şeşen (2010) tarafindan Türkçe'ye uyarlanarak geçerlemesi yapılan ölçek kullanılmıştır. Altı maddeli ölçek, çalışanların örgütlerine duydukları bağlılığg genel örgütsel bağlılık olarak ele almakta ve tek boyutta değerlendirmektedir. Ölçek "Geleceğimin çalıştığım kuruma yakından bağlı olduğunu hissediyorum", "Eğer çalıştığım kurumun iyiliği için gerekli ise bireysel iyiliğimi feda edebilirim", "Çalıştığım kurum ile aramdaki bağlar son derece güçlüdür" gibi yarg1 cümlelerinden oluşmakta olup, ölçek maddelerinden birisi ters kodlanmıştır. Ölçekteki sorular, 5'li Likert tipinde düzenlenmiştir. DFA sonuçları Tablo 2'dedir. Ölçeğin güvenilirliği Cronbach Alfa'sı 0,740 olarak tespit edilmiştir.

\subsubsection{Sinizm Ölçeği (SÖ)}

Çalışanların örgütsel sinizm tutumlarını ölçen Örgütsel Sinizm Ölçeği (ÖSÖ), Brandes, Dharwadkar ve Dean (1999) tarafindan geliştirilmiş olan 13 maddeden oluşmaktadır. Ölçek, Karacaoğlu ve İnce (2012) tarafindan Türkçe'ye uyarlanmış ve geçerlenmiştir. Ölçekte bilişsel (5 madde), duyuşsal (4 madde) ve davranışsal (4 madde) olmak üzere üç boyut yer almaktadır. Söz konusu alt boyutlar, her ne kadar birbirlerinden kavramsal olarak bağımsız olsa da; aynı zamanda tek bir kuramsal üst yapı olarak belirli ve büyük bir güce dayanan olumsuz bir tutuma işaret etmektedir (Andersson, 1996; Andersson ve Bateman, 1997; Dean vd., 1998). Bu bağlamda analizlerde, sinizm ölçeğinin tek tek boyutsal etkileri yerine, söz konusu üst yapının çalışanların sinik tutumlarını öne çıkararak, bütüncül etkisini görmek amacıyla tüm boyutlarının toptan etkisi (ikincil seviyesi) ele alınmıştır. Ölçekteki sorular, 5'li Likert tipinde düzenlenmiştir. Ölçek, "Çalıştığım kurumda, söylenenler ile yapılanların farklı olduğuna inanıyorum", "Çalıştığım kurumun politikaları, amaçları ve uygulamaları arasında çok az ortak bir yön vardır”, "Çalıştığım kurumda, bir uygulamanın yapılacağı söyleniyorsa, bunun gerçekleşip gerçekleşmeyeceği konusunda kuşku duyarım” gibi yargi cümlelerinden oluşmaktadır. DFA sonuçları Tablo 3'dedir. Ölçeğin güvenilirliği Cronbach Alfa'sı 0,885 olarak bulunmuştur.

Tablo 2. Ölçeklerin Güvenilirlik (Cronbach Alfa-CAL Değerleri) ve Geçerlilikleri (DFA Sonuçlar1-Model Uyum Değerleri)

\begin{tabular}{llllllll} 
Ölçek & CAL & $\Delta \chi^{2} / \mathrm{df}$ & NFI & GFI & CFI & RMSEA \\
\hline
\end{tabular}

\begin{tabular}{lcccccc}
\hline $\begin{array}{l}\text { Psikolojik } \\
\text { Sermaye }\end{array}$ & 0,873 & 3,820 & 0,910 & 0,920 & 0,950 & 0,077 \\
\hline İş Tatmini & 0,859 & 0,049 & 0,998 & 0,995 & 0,999 & 0,020 \\
\hline $\begin{array}{l}\text { Örgütsel } \\
\text { Bağllık }\end{array}$ & 0,740 & 1,427 & 0,988 & 0,990 & 0,996 & 0,037 \\
\hline Sinizm & 0,885 & 4,403 & 0,912 & 0,932 & 0,930 & 0,060 \\
\hline
\end{tabular}

\subsection{Araştırma Değişkenlerine İlişkin Bulgular}

\subsubsection{Araştırma Değişkenlerine İlişkin Tanımlayıcı Bulgular}

Tablo 3 'te araştırma değişkenlerine ait tanımlayıcı bulgulara yer verilmiştir. Buna göre, katılımcıların 5'ki likert ölçeğine göre psikolojik sermaye seviyeleri ortalama 4,36 iş tatmini seviyeleri ortalama 3,45 örgütsel bağlılık seviyeleri ortalama 3,99 ve sinizm puanları ise ortalama 2,08 şeklindedir. $\mathrm{Bu}$ ortalamalara göre en yüksek seviye psikolojik sermayede tespit edilmiştir. Beklenildiği üzere katılımcıların sinizm değerleri en düşük çıkmıştır. Psikolojik sermayeden sonra ortalamanın en yüksek olduğu araştırma değişkeni ise örgütsel bağlılıktır.

Tablo 3. Araştırma Değişkenlerine İlişkin Tanımlayıcı Bulgular

\begin{tabular}{lccccc}
\hline \multicolumn{1}{c}{ Değişkenler } & N & Min. & Maks. & Ort. & Std. Sapma \\
\hline Psikolojik Sermaye & 295 & 2,71 & 5,29 & 4,36 & 0,496 \\
\hline İs Tatmini & 295 & 1,00 & 5,00 & 3,45 & 0,800 \\
\hline Örgütsel Bağll1ık & 295 & 2,00 & 3,99 & 3,99 & 0,614 \\
\hline Sinizm & 295 & 1,00 & 4,08 & 2,08 & 0,612 \\
\hline
\end{tabular}

Tablo 4'te araştırma değişkenlerinin birbiri ile ilişkisini gösteren korelasyon tablosuna yer verilmiştir. Buna göre, $\mathrm{p}=0.01$ anlamlılık seviyesinde, araştırma değişkenlerinin hepsi birbiriyle istatistiksel olarak anlamlı bir korelasyona sahiptir. Korelasyon değerlerine bakıldığında, örgütsel bağlılık ve iş tatmini arasındaki olumlu ve orta seviyedeki korelasyonun en yüksek olduğu, araştırmanın bağımsız değişkeni olan psikolojik sermaye ile ise en yüksek korelasyon ilişkisinin orta seviyede ve olumlu olarak örgütsel bağlılık ile $(0,449)$ olduğu tespit edilmiştir. Ayrıca psikolojik sermaye ile iş tatmini arasında orta seviyede olumlu bir korelasyon $(0,327)$ ve sinizm ile de olumsuz ve düşük seviyede $(0,227)$ bir korelasyon mevcuttur.

Tablo 4. Araştırma Değişkenleri Arasındaki Korelasyon Analizine İlişkin Bulgular

\begin{tabular}{lcccc}
\hline \multicolumn{1}{c}{ Değişkenler } & $\begin{array}{c}\text { Psikolojik } \\
\text { Sermaye }\end{array}$ & İş Tatmini & $\begin{array}{l}\text { Örgütsel } \\
\text { Bağl1lik }\end{array}$ & Sinizm \\
\hline $\begin{array}{l}\text { Psikolojik } \\
\text { Sermaye }\end{array}$ & 1 & & & \\
\hline İş Tatmini & $\begin{array}{c}0,327^{* *} \\
(\mathrm{p}=0,000)\end{array}$ & 1 & & \\
\hline $\begin{array}{l}\text { Örgütsel } \\
\text { Bağl1lık }\end{array}$ & $\begin{array}{c}0,449^{* *} \\
(\mathrm{p}=0,000)\end{array}$ & $\begin{array}{c}0,460^{* *} \\
(\mathrm{p}=0,000)\end{array}$ & 1 & \\
\hline Sinizm & $\begin{array}{c}-0,227^{* *} \\
(\mathrm{p}=0,000)\end{array}$ & $\begin{array}{c}-0,351^{* *} \\
(\mathrm{p}=0,000)\end{array}$ & $\begin{array}{c}-0,360^{* *} \\
(\mathrm{p}=0,000)\end{array}$ & 1 \\
\hline${ }^{*} \mathrm{p}<0,05 ;{ }^{* *} \mathrm{p}<0,01$ & & & &
\end{tabular}

\subsubsection{Araştırma Modelinin Test Edilmesi ve Bulgular}

Tablo 5'te araştırmanın bağımlı değişkenleri olan iş tatmini, örgütsel bağlılık ve sinizmin bağımsız değişken olan psikolojik sermaye ile yordanmasına ilişkin regresyon analizi sonuçları yer almaktadır. Buna göre, psikolojik 
sermaye her üç bağımlı araştırma değişkenini de istatistiksel olarak anlamlı şekilde açıklayabilme etkisine sahiptir. Psikolojik sermaye ile iş tatmini arasındaki ilişkiye bakıldığında; iş tatminindeki olumlu yöndeki değişmenin (artışın) \% 10,4'ü ve örgütsel bağlılıkta ise \% 19,9'u psikolojik sermayedeki olumlu değişimden kaynaklandığı ve çalışanların sinizm seviyelerindeki azalmanın (olumlu bir sonuç olarak değerlendirilir) \% 4,9'unun psikolojik sermayedeki artıştan kaynaklandığı görülmektedir.

Tablo 5. İş Tatmini, Örgütsel Bağlılık ve Sinizmin Psikolojik Sermaye ile Yordanmasına İlişkin Regresyon Analizi Sonuçları

\begin{tabular}{|c|c|c|c|c|}
\hline \multirow[t]{2}{*}{ Model } & $\begin{array}{c}\text { Standardize } \\
\text { Edilmemiş Katsayıla }\end{array}$ & \multirow{2}{*}{$\begin{array}{c}\begin{array}{c}\text { Standardize } \\
\text { Katsayılar }\end{array} \\
\text { Beta }\end{array}$} & \multirow[t]{2}{*}{$\mathrm{t}$} & \multirow[t]{2}{*}{$\mathrm{p}$} \\
\hline & Std. Hata & & & \\
\hline Psikolojik Sermaye & 0,087 & 0,327 & 6,078 & 0,000 \\
\hline \multicolumn{5}{|c|}{$\begin{array}{l}\text { Bağımlı Değişken: İş Tatmini } \\
R=0,327 \text { Düzeltilmiş } R^{2}=0,104 \quad F=36,942 \quad p=0,000\end{array}$} \\
\hline Psikolojik Sermaye & 0,063 & 0,449 & 8,826 & 0,000 \\
\hline \multicolumn{5}{|c|}{$\begin{array}{l}\text { Bağımlı Değişken: Örgütsel Bağlılık } \\
R=0,449 \text { Düzeltilmiş } R^{2}=0,199 \quad F=77,896 \quad p=0,000\end{array}$} \\
\hline Psikolojik Sermaye & $-0,281$ & $-0,227$ & $-4,107$ & 0,000 \\
\hline $\begin{array}{l}\text { Bağımlı Değişken: } \mathrm{S} \\
\mathrm{R}=0,227 \text { Düzeltiln }\end{array}$ & Ş $\mathrm{R}^{2}=0,049 \quad \mathrm{~F}=16,86$ & $65 \mathrm{p}=0,000$ & & \\
\hline
\end{tabular}

\section{5. Çıkarımlar ve Sonuç}

$\mathrm{Bu}$ çalışmada, psikolojik sermayenin iş tatmini, örgütsel bağl1lık ve sinizm üzerindeki etkisinin ortaya çıkarılmasını amaçlanmıştır. Araştırmadan elde edilen bulgulara göre; psikolojik sermaye, iş tatmini, örgütsel bağlılık ve sinizm üzerinde etkilidir. Diğer bir ifade ile çalışanların iş tatmini, örgütsel bağlılık ve sinizm seviyelerindeki değişim belli bir oranda psikolojik sermayedeki değişism ile açıklanabilmektedir.

Araştırmada psikolojik sermayenin en çok yordadığı bağımlı değişken örgütsel bağlıktır. Günümüzde bir iş görenlerin, özellikle de beyaz yakalı görenlerin çalıştığı örgütlerden ayrılmasının örgüte bir maliyet yüklüyor olması, yöneticiler ve işverenler tarafindan önemsenen bir durum haline gelmiştir. İş değiştirmenin geçmişle kıyaslandığında artan bir seyir izlemesi, bu önemi daha da pekiştirmektedir. Bu kapsamda, örgütsel bağlılığı yüksek çalışanların, sadece örgüte kalmalarının, örgüte kattığ değer değil, ayrılmalarının da örgüte kaybettirdiği bir değer olarak konunun ele alınması olması ön plana çıkmıştır Dolayısıyla, örgütsel bağlılığı arttıracak, örgütsel bağlılığ1 yordayacak bir değişken olarak psikolojik sermayenin, önemi yapılan bu çalışma ile teyit edilmiştir. Araştırmadan elde edilen bu bulgu daha önce konu ile ilgili Çetin (2011a), Etebarian vd. (2012), Larson ve Luthans (2006) ve Youssef ve Luthans (2007) tarafından yapılan araştırmalarla uyumludur.

İş tatmini çalışanların yaptığı işte verimli olmalarında en büyük etkenlerden biridir. Dolayısıyla, iş tatmini yüksek bireyler örgütler açısından verimlilik ve etkinliğin sağlanmasında vazgeçilmez bir paya sahiptir. $\mathrm{Bu}$ açıdan değerlendirildiğinde, iş tatmini üzerinde etkili olan değişkenlerin tespit edilmesi ilgili yazında de ön plana çıkmıştır. Yapılan bu çalışma kapsamında da psikolojik sermayenin çalışanların iş tatmini üzerinde etkili olduğu tespit edilmiştir. Elde edilen bu bulgu, psikolojik sermaye ile iş tatmini arasında pozitif yönde bir ilişki olduğunu bulan araştırmalar (Örn., Chandrasekar ve Chidambaram, 2015; Çetin, 2011a; Goldsmith, Veum ve Darity, 1997; Judge ve Llies, 2004; Larson ve Luthans, 2006; Luthans vd., 2007; Turner vd., 2002; Youssef ve Luthans, 2007; Watson, 2002) ile uyumludur.

Psikolojik sermayesi yüksek çalışanların işe alınıp ve istihdam edilmesi, çalışanların psikolojik sermayesini arttırmaya yönelik örgüt içinde yapılacak faaliyet ve düzenlemelere önem verilmesi iş tatminini etkileyerek olumlu bir sonuç alınmasına yol açacaktır. Bu nedenle, örgütsel açısından çok önemli bir yere sahip olan iş tatminini yordayan psikolojik sermayenin, uygulayıcılar tarafından daha çok dikkate alınarak teoriden pratiğe aktarılması bir gereklilik olarak karşımıza çıkmaktadır.

Örgütsel başarı açısından yapılması gerekenler kadar yapılmaması gerekenlerinde dikkate alınması gerekir. $\mathrm{Bu}$ kapsamda, sinizm son yıllarda yazında üzerinde durulan önemli bir başka örgütsel sonuç değişkeni haline gelmiştir. Yapılan bu çalışmadan elde edilen bulgulara göre, çalışanların psikolojik sermayeleri sinizmin seviyesini azaltmaktadır. Bu bağlamda, psikolojik sermayesi yüksek olan işgörenlerin sahip olduğu pozitif duygu, düşünce ve davranışların, örgütsel sinizmin etkilerini azaltabileceği bulgusu elde edilmiştir. Böylece elde edilen bu bulgu, psikolojik sermaye ile sinizm arasında negatif yönde bir ilişki olduğunu bulan benzer araştırmalarla (Örn., Avey vd., 2008; Avey, Luthans ve Youssef, 2008a; Avey vd., 2008b; Avey, Luthans ve Youssef, 2010) uyumludur. Böyle bir bulgu örgütsel başarı açısından kayda değer bir bulgudur. Çünkü, olumsuz tutum ve davranışların örgüte verdiği zararlar belki somut olarak henüz günümüz örgütlerinde tam olarak ölçülemese de, bu zararın maddi ve manevi ciddi boyutlarda olabileceğini söylemek yanlış olmayacaktır. $\mathrm{Bu}$ nedenle, olumsuz davranışları azaltacak bir değişken olan psikolojik sermaye her seviyedeki yönetici tarafından önemsenmesi gereken bir değişken olarak karşımıza çıkmaktadır. Aynı zamanda insan kaynakları yönetici ve çalışanlarının özellikle işe alımlarda dikkate alması gereken bir boyut olarak psikolojik sermaye, istihdam sürecinde de kendini ön plana çıkarmaktadır.

Araştırma sınırlılıkları kapsamında; uygulanan anketler ile elde edilen bulgular, verilerin toplanmasinda kullanılan örnekleme göre değişiklik gösterebileceğinden araştırmanın bulguları, verilerin toplandığı örneklem ile sınırlıdır. $\mathrm{Bu}$ nedenle farklı örneklemler için modelin test edilmesi gerekmektedir. Çalışma kapsamında irdelenen değişkenler, zaman içinde değişime uğrayabileceğinden araştırmanın bulguları, uygulandığı zaman dilimi ile sınırlıdır. Araştırmada kullanılan ölçekler, bireylere aynı anda yöneltilen değerlendirme maddelerinden oluşmakta ve bu bağlamda bireylerin algılamalarını değerlendirmektedir. Bu nedenle sonuçlar değerlendirilirken bu husus dikkate alınmalıdır.

Psikolojik sermayenin gelişime açık olması, kültürel bağlamın göz ardı edilmemesini gerekmektedir. Bu nedenle gelecekte yapılacak araştırmalarda psikolojik sermayenin yapılan bu araştırma değişkenlerine ek olarak kültürel bağlam kapsamında ve kültürler arası uygulamalarının 
dikkate alınarak ele alınması önemli bulguların elde edilmesine yardımcı olabilecektir.

\section{Kaynakça}

Abraham, R. (2000). Organizational cynicism: Bases and consequences. Genetic, Social, and General Psychology Monographs, 126 (3), 269-292.

Agho, A.O., Price, J.L. ve Mueller, C.W. (1992). Discriminant validity of measures of job satisfaction, positive affectivity and negative affectivity. Journal of Occupational and Organizational Psychology, 65: 185196.

Akçay, V.H. (2011). Pozitif psikolojik sermaye kavramı ve işletmelerde sürdürülebilir rekabet üstünlügünü sağlamadaki rolü. Gazi Üniversitesi İktisadi ve İdari Bilimler Fakültesi Dergisi, 13 (1), 73-98.

Allen, N.J. ve Meyer, J.P. (1990). The measurement and antecedents of affective, continuance and normative commitment to the organization. Journal of Occupational Psychology, 63: 1-18.

Andersson, L.M. (1996). Employee cynicism: An examination using a contract violation framework. Human Relations, 49 (11), 1395-1418.

Andersson, L.M. ve Bateman, T.S. (1997). Cynicism in the workplace: Some causes and effects. Journal of Organizational Behavior, 18 (5), 449-469.

Ardichvili, A. (2011). Invited reaction: Meta-analysis of the impact of psychological capital on employee attitudes, behaviors, and performance. Human Resource Development Quarterly, 22: 153-156.

Avey, J.B., Hughes, L.W., Norman, S.M. ve Luthans, F. (2008). Using positivity, transformational leadership and empowerment to combat employee negativity. Leadership and Organization Development Journal, 29 (2), 110-126.

Avey, J.B., Luthans, F., Smith, R. M. ve Palmer, N.F. (2010). Impact of positive psychological capital on employee well-being over time. Journal of Occupational Health Psychology, 15 (1), 17-28.

Avey, J.B., Luthans, F. ve Youssef, C.M. (2008a). The additive value of positive psychological capital in predicting work attitudes and behaviors. Leadership Institute Faculty Publications, Paper 6: 1-45.

Avey, J.B., Luthans, F. ve Youssef, C.M. (2010). The additive value of positive psychological capital in predicting work attitudes and behaviors. Journal of Management, 36 (2), 430-452.

Avey, J.B., Wernsing, T.S. ve Luthans, F. (2008b). Can positive employees help positive organizational change? Impact of psychological capital and emotions on relevant attitudes and behaviors. The Journal of Applied Behavioral Science, 44 (1), 48-70.

Avolio, B.J. ve Luthans, F. (2006). The high impact leader: Moments matter in accelerating authentic leadership development. New York: McGraw-Hill.

Babin, B. ve Griffin, M. (1998). The nature of satisfaction: an updated examination and analysis. Journal of Business Research, 41 (2), 127-136.

Bakker, A.B. ve Schaufeli, W.B. (2008). Positive organizational behavior: Engaged employees in flourishing organizations. Journal of Organizational Behavior, 29: 147-154.

Barca, M. (2005). Stratejik yönetim düşüncesinin evrimi: bilimsel bir disiplinin oluşum hikâyesi. Yönetim Araştırmaları Dergisi, 5 (1), 7-39.

Barefoot, J.C., Dodge, K.A., Peterson, B.L., Dahlstrom, W.G. ve Williams, R.B. (1989). The Cook-Medley hostility scale: Item content and ability to predict survival. Psychosomatic Medicine, 51: 46-57.

Becker, T., Billings, E., Eveleth, D. ve Gilbert, N. (1996). Foci and bases of employee commitment: Implications for job performance. Academy of Management Journal, 39 (2), 464-482.

Bedeian, A.G. (2007). Even if the tower is "ivory," it isn't "white:" understanding the consequences of faculty cynicism. Academy of Management Learning \& Education, 6 (1), 9-32.

Bernerth, J.B., Armenakis, A.A., Feild, H.S. ve Walker H.J. (2007). Justice, cynicism, and commitment a study of important organizational change variables. The Journal of Applied Behavioral Science, 43 (3), 309-319.

Bommer, W.H., Rich, G. ve Rubin, R.S. (2005). Changing attitudes about change: longitudinal effects of transformational leader behavior on employee cynicism about organizational change. Journal of Organizational Behavior, 26 (7), 733-753.

Bono, J.E., ve Judge, T.A. (2003). Core self-evaluations: a review of the trait and its role in job satisfaction and job performance. European Journal of Personality, 17: 518.

Bowling, N.A., Wang, Q. ve Li, H.Y. (2012). The moderating effect of core self-evaluations on the relationships between job attitudes and organisational citizenship behavior. Applied Psychology: An International Review, 61 (1), 97-113.

Brandes, P. (1997). Organizational cynicism: Its nature, antecedents, and consequences. Yayınlanmamış Doktora Tezi, Cincinnati University.

Brandes, P. ve Das, D. (2006). Locating behavioral cynicism at work: Construct issues and performance implications. P.L. Perrewe ve D.C. Ganster (Ed.), Employee health, coping and methodologies (s.233266). New York: JAI Press.

Brandes, P., Das, D. ve Hadeni, M. (2006). Organizational cynicism: A field examination using global and local social exchange relationships and workplace outcomes. G.B. Grean ve J.A. Grean (Ed.), Sharing network 
leadership (s.191-224). Greenwich, CT: Information Age Publishing.

Brandes, P., Castro, S.L., James, M.S.L., Martinez, A.D., Matherly, T.A., Ferris, G.R. ve Hochwarter, W.A. (2008). The interactive effects of job insecurity and organizational cynicism on work effort following a layoff. Journal of Leadership \& Organizational Studies, 14 (3), 233-247.

Byrne, Z. ve Hochwarter, W.A. (2008). Perceived organizational support and performance: Relationships across levels of organizational cynicism. Journal of Managerial Psychology, 23: 54-72.

Cameron, K. S. (2005). Organizational effectiveness: its demise and re-emergence through positive organizational scholarship. K.G. Smith ve M.A. Hitt (Ed.), Great minds in management (s.304-330). New York: Oxford University Press.

Cameron, K.S., Dutton, J.E., ve Quinn, R.E. (2003). Organizational virtuousness and performance. K.S. Cameron, J.E. Dutton ve R.E. Quinn (Ed.), Positive organizational scholarship foundations of a new discipline (s.48-65). San Francisco: Berrett-Koehler.

Cartwright S. ve Holmes N. (2006). The meaning of work: the challenge of regaining employee engagement and reducing cynicism. Human Resource Management Review, 16: 199-208.

Chandrasekar, T. ve Chidambaram, V. (2015). The impact of big five personality traits and positive psychological strengths towards job satisfaction: A review. Periodica Polytechnica Social and Management Sciences, 23 (2), $142-150$

Cole, M.S., Bruch, H. ve Vogel, B. (2006). Emotion as mediators of the relations between perceived supervisor support and psychological hardiness on employee cynicism. Journal of Organizational Behavior, 27: $463-$ 484.

Colquitt, J.A., Conlon, D.E., Wesson, M.J., Porter, C.O. ve Ng, K.Y. (2001). Justice at the millennium: A metaanalytic review of 25 years of organizational justice research. Journal of Applied Psychology, 86 (3), 425445.

Colquitt, J.A., Lepine, J.A. ve Wesson, M.J. (2015). Organizational behavior: Improving performance and commitment in the workplace, 4th Ed. New York: McGraw-Hill.

Compton, W.C. (2005). Introduction to positive psychology. Belmont, CA: Thompson Wadsworth.

Cook, WW. ve Medley, D.M. (1954). Proposed hostility and pharisaic-virtue scale for the MMPI. Journal of Applied Psychology, 38 (6), 414-418.

Crook, T. R., Ketchen Jr., D. J., Combs, J. G. ve Todd, S. Y. (2008). Strategic resources and performance: A meta-analysis. Strategic Management Journal, 29: 1141-1154.

Çelik, M., Turunç, Ö. ve Bilgin, N. (2014). Çalışanların örgütsel adalet algılarının psikolojik sermaye üzerine etkisi: Çalışanların iyilik halinin düzenleyici rolü. Dokuz Eylül Üniversitesi Sosyal Bilimler Enstitüsü Dergisi, 16 (4), 559-585.

Çetin, F. (2011). Örgütsel vatandaşlık davranışlarının açıklanmasında örgütsel bağlılık, iș tatmini, kişilik ve örgüt kültürünün rolü. Yayınlanmamış Doktora Tezi, Ankara Üniversitesi Sosyal Bilimler Enstitüsü İşletme Anabilim Dalı, Ankara.

Cetin, F. (2011a). The effects of the organizational psychological capital on the attitudes of commitment and satisfaction: A public sample in Turkey. European Journal of Social Sciences, 21 (3), 373-380.

Çetin, F. ve Basım, H.N. (2011). Psikolojik dayanıklılığın iş tatmini ve örgütsel bağl1lık tutumlarındaki rolü. $\dot{I}_{S ̧}$ Güç Endüstri Iliş̧kileri ve Insan Kaynakları Dergisi, 13 (3), 79-94.

Çetin, F. ve Basım, H.N. (2012). Örgütsel psikolojik sermaye: Bir ölçek uyarlama çalıșması. TODAIE AMME Iddaresi Dergisi, 45 (1), 121-137.

Davis, W.D. ve Gardner, W.L. (2004). Perceptions of politics and organizational cynicism: An attributional and leader-member exchange perspective. The Leadership Quarterly, 15:439-465.

Dean, J.W., Brandes, P. ve Dharwadkar, R. (1998). Organizational cynicism. Academy of Management Review, 23 (2), 341-352.

DeCotiis, T.A. ve Summers T.P. (1987). A Path analysis of a model of the antecedents and consequences of organizational commitment. Human Relations, 40 (7), $445-470$

Donaldson, S.I. ve Ko, I. (2010). Positive organizational psychology, behavior, and scholarship: A review of the emerging literature and evidence base. The Journal of Positive Psychology, 5 (3), 177-191.

Eaton, J.A. (2000). A social motivation approach to organizational cynicism. Yayınlanmamış Doktora Tezi, Graduate Program in Psychology, York University, Toronto.

Eisenberger, R., Fasolo, P. ve Davis-Lamastro, V. (1990). Perceived organizational support and employee diligence, commitment and innovation. Journal of Applied Psychology, 75: 51-59.

Ensher, E.A., Grant-Vallone, E.J. ve Donaldson, S.I. (2001). Effects of perceived discrimination on job satisfaction, organizational commitment, organizational citizenship behavior, and grievances. Human Resource Development Quarterly, 12 (1), 53-72.

Etebarian, A., Tavakoli, S. ve Abzari, M. (2012). The relationship between psychological capital and organizational commitment. African Journal of Business Management, 6 (14), 5057-5060.

Etzioni, A. (1961). A comparative analysis of complex organizations. New York: Free Press.

Ferres, N. ve Connel, J. (2004). Emotional intelligence in leaders: An antidote for cynicism towards change. Strategic Change, 13 (2), 61-71. 
Fleming, P. (2005). Workers playtime? Boundaries and cynicism in a "culture of fun" program. The Journal of Applied Behavioral Science, 41 (1), 285-303.

Folger, R. ve Cropanzano, (1998). Organizational justice and human resource management. London: Sage Publications Inc.

Froh, J. (2004). The history of positive psychology: truth be told. New York State (NYS) Psychologist: 18-20.

Gable, S.L. ve Haidt, J. (2005). What (and why) is positive psychology? Review of General Psychology, 9 (2), 103 110.

George, J.M., Reed, T.F., Ballard, K.A., Colin, I. ve Fielding, I. (1993). Contact with AIDS patients as a source of work-related distress: Effects of organizational and social support. Academy of Management Journal, 36: 157-171.

Goldsmith, A.H., Veum, J.R. ve Darity, W.Jr. (1997). The impact of psychological and human capital on wages. Economic Inquiry, XXXV: 815-829.

Greenberg, J. ve Baron, R.A. (2000). Behavior in organizations, 7th Ed. New Jersey: Prentice Hall.

Grusky, O. (1966). Career mobility and organizational commitment. Administrative Science Quarterly, 10: 488-503.

Gutierrez, A., Candela, L. ve Carver, L. (2012). The structural relationships between organizational commitment, global job satisfaction, developmental experiences, work values, organizational support, and person-organization fit among nursing faculty. Journal of Advanced Nursing, 68 (7), 1601-1614.

Gürbüz, S. ve Sığrı, Ü. (2013). Örgütsel davranışa giriş. Ü. Sığrı ve S. Gürbüz (Ed.), Örgütsel davranış (s.1-44). İstanbul: Beta Yayınları.

Gygax, M., Ticino, L. ve Fitzgerald, S.P. (2011). Enriching the positive organizational behavior framework with wisdom. International Journal of Business Research, 11 (2), 23-41.

Hackman, J.R. ve Oldham, C.R. (1975). Development of the job diagnostic survey. Journal of Applied Psychology, 60: 159-170.

Hefferon, K. ve Boniwell, I. (2011). Positive psychology: Theory, research and applications. New York: McGraw-Hill.

Huang, Y.H., Shawaand, W. ve Chen, P. (2004). Worker perceptions of organizational support and return-towork policy: Associations with post-injury job satisfaction, Work, 23 (3), 225-232.

Irving, P.G., Coleman, D.F. ve Bobocel, D.R. (2005). The moderating effect of negative affectivity in the procedural justice-job satisfaction relation. Canadian Journal of Behavioral Science, 37 (1), 20-32.

James, S.M. (2005). Antecedents and consequences of cynicism in organizations: An examination of potential positive and negative effects on school systems. Yayınlanmamış Doktora Tezi, College of Business, Florida State University.
Judge, T.A., Hulin, C.L. ve Dalal, R.S. (2009). Job satisfaction and job affect, the Oxford handbook of industrial and organizational psychology. New York: Oxford University Press.

Judge, T.A. ve Llies, R. (2004). Research edge: Is positiveness in organizations always desirable? The Academy of Management Executive, 18 (4), 151-155.

Judge, T.A., Locke, E.A. ve Durham, C.C. (1997). The dispositional causes of job satisfaction: A core evaluations approach. Research in Organizational Behavior, 19: 151-188.

Judge, T.A., Locke, E.A., Durham, C.C. ve Kluger, A.N. (1998). Dispositional effects on job and life satisfaction: The role of core evaluations. Journal of Applied Psychology, 83: 17-34.

Kanter, D.L. ve Mirvis, P.H. (1989). The cynical Americans: Living and working in an age of discontent and disillusion. San Francisco: Jossey-Bass.

Kanter, R.M. (1968). Commitment and social organization: a study of commitment mechanisms in utopian communities. American Sociological Review, 33 (4), 499-517.

Kaplan, M. ve Öğüt, A. (2012). Algılanan örgütsel destek ile örgütsel bağlılık arasındaki ilişkinin analizi: otel işletmelerinde bir uygulama. Süleyman Demirel Üniversitesi İktisadi ve İdari Bilimler Fakültesi Dergisi, 17 (1), 387-401.

Katz, D. ve Kahn R.L. (1966). The social psychology of organizations. New York: Wiley.

Kauffman, C. (2006). Positive psychology: the science at the heart of coaching. D.R. Stober ve A.M. Grant (Ed.), Evidence based coaching handbook putting best practices to work for your clients (s.219-253). New Jersey: John Wiles \& Sons.

Kittinger, J.D., Walker, A.G., Cope, J.G. ve Wuensch, K.L. (2009). The relationship between core self-evaluations and affective commitment. Institute of Behavioral and Applied Management, 68-92.

Kobau, R., Seligman, M.E.P., Peterson, C., Zack, M.M., Chapman, D. ve Thompson, W. (2011). Improving uptake of essential services mental health promotion in public health: perspectives and strategies from positive psychology. American Journal of Public Health, August 2011, 101 (8), e2-e9.

Kristof-Brown, A.L., Zimmerman, R.D. ve Johnson, E.C. (2005). Consequences of individuals' fit at work: A meta-analysis of person-job, person-organization, person-group, and person-supervisor fit. Personnel Psychology, 58: 281-342.

Larson, M. ve Luthans, F. (2006). Potential added value of psychological capital in predicting work attitudes. Journal of Leadership and Organizational Studies, 13 (1), 45-62.

Linley, P.A., Joseph, S., Harrington, S. ve Wood, A.M. (2006). Positive psychology: Past, present, and (possible) future. The Journal of Positive Psychology, 1 (1), 3-16. 
Locke, E.A. (1976). The nature and causes of job satisfaction. Dunnette, M.D. (Ed.) Handbook of Industrial and Organizational Psychology, Vol.1, 12971343.

Luthans, F. (2002b). Positive organizational behavior: Developing and managing psychological strengths. Academy of Management Executive, 16 (1), 57-72.

Luthans, F., Avolio, B.J. Avey, J.B. ve Norman, S.M. (2007). Positive psychological capital: Measurement and relationship with performance and satisfaction. Personnel Psychology, 60: 541-572.

Luthans, F., Luthans, K.W. ve Luthans, B.C. (2004). Positive psychological capital: Beyond human and social capital. Business Horizons, 47 (1), 45-50.

Luthans, F., Norman, S.M., Avolio, B.J. ve Avey, J.B. (2008a). The mediating role of psychological capital in the supportive organizational climate-employee performance relationship. Journal of Organizational Behavior, 29: 219-238.

Luthans, F. ve Youssef, C.M. (2004). Human, social, and now positive psychological capital management: Investing in people for competitive advantage. Organizational Dynamics, 33 (2), 143-160.

Luthans, F., Youssef, C.M. ve Avolio, B.J. (2007a). Psychological capital: Developing the human competitive edge. Oxford, UK: Oxford University Press.

Maslow, A.H. (1954). Motivation and personality. New York: Harper.

McDonald, D.J. ve Makin, P.J. (2000). The psychological contract, organizational commitment and job satisfaction of temporary staff. Leadership and Organization Development Journal, 21 (2), 84-91.

McMurray, A.J., Pirola-Merlo, A., Sarros, J.C. ve Islam, M.M. (2010). Leadership, climate, psychological capital, commitment, and wellbeing in a non-profit organization. Leadership \& Organization Development Journal, 31 (5), 436-457.

Meyer, J.P. ve Allen, N.J. (1991). A three-component conceptualization of organizational commitment. Human Resources Management Review, 1: 61-89.

Meyer, J.P. ve Allen, N.J. (1997). Commitment in the workplace: Theory, research and application. London: Sage Publications.

Meyer, J., Stanley, D., Herscovitch L. ve Topolnytsky, L. (2002). Affective, continuance, and normative commitment to the organization: Meta-analysis of antecedents, correlates, and consequences. Journal of Vocational Behavior, 61 (1), 20-52.

Meyerson, D.E. (1990). Uncovering socially undesirable emotions: Experiences of role ambiguity in organizations. American Behavioral Scientist, 33 (3), 296-307.

Mirvis, P.H. ve Kanter, D.L. (1991). Beyond demography: A psychographic profile of the workforce. Human Resource Management, 30 (1), 45-68.

Moorman, R., Blakely, G. ve Niehoff, B. (1998). Does perceived organizational support mediate the relationship between procedural justice and organizational citizenship behavior? Academy of Management Journal, 41 (3), 351-357.

Mowday, R.T., Porter, L.W. ve Steers, R.M. (1982). Employee organization linkages: The psychology of commitment, absenteeism, and turnover. New York: Academic Press.

Naus, A.J.A.M. (2007). Organizational cynicism on the nature, antecedents, and consequences of employee cynicism toward the employing organization, Yayınlanmamış Doktora Tezi, Maastricht University.

Newman, A., Üçbaşaran, D., Zhu, F. ve Hirst, G. (2014). Psychological capital: A review and synthesis. Journal of Organizational Behavior, 35: S120-S138.

Nitesh, S., Nandakumar, V.M. ve Asok, K.S. (2013). Role of pay as perceived organizational support contributes to employee's organizational commitment. Advances in Management, 6 (8), 52-54.

Örücü, E., Yumuşak, S. ve Bozkır, Y. (2006). Kalite yönetimi çerçevesinde bankalarda çalışan personelin iş tatmini ve iş tatminini etkileyen faktörlerin incelenmesine yönelik bir araştırma. Yönetim ve Ekonomi Dergisi, 13 (1), 39-51.

Özcan, E.D. (2011). Kişilik bakış açısından örgüt yapısı ve iş tatmini. İstanbul: Beta Yayınları.

Özgener, Ş., Öğüt, A. ve Kaplan, M. (2008). İşgörenişveren ilişkilerinde yeni bir paradigma: örgütsel sinizm. M. Özdevecioğlu ve H. Kaplan (Ed.), Örgütsel davranışta seçme konular (s.53-72). Ankara: G.Ü.V. İlke Yayınevi.

Paşamehmetoğlu, A. ve Yeloğlu, H.O. (2013). Motivasyon. Ü. Sığrı ve S. Gürbüz (Ed.), Örgütsel davranış (s.137174). İstanbul: Beta Yayınları.

Peterson, S.J., Luthans, F., Avolio, B.J., Walumbwa, F.O. ve Zhang, Z. (2011). Psychological capital and employee performance: A latent growth modeling approach. Personnel Psychology, 64: 427-450.

Premeaux, S.R. ve Mondy, R.W. (1986). Problem employees: The cynic. Management Solutions, 14-17.

Qadeer, F. ve Jaffery, H. (2014). Mediation of psychological capital between organizational climate and organizational citizenship behavior. Pakistan Journal of Commerce and Social Sciences, 8 (2), 453470.

Robbins, S.P. ve Judge, T.A. (2012). Örgütsel davranış. (Çev.: Prof.Dr. İnci Erdem). İstanbul: Nobel.

Rode, J.C. (2004). Job satisfaction and life satisfaction revisited: A longitudinal test of an integrated model. Human Relations, 57 (9), 1205-1230.

Saekoo, A. (2011). Examining the effect of trust, procedural justice, perceived organizational support, commitment, and job satisfaction in Royal Thai Police: The empirical investigation in social exchange perspective. Journal of Academy of Business and Economics, 11 (3), 229-237.

Schultz, D.P ve Schultz, S.E. (1990). Psychology and industry today: An introduction to industrial and 
organizational psychology, 5th Ed. New York: MacMillan.

Scott, W.R. ve Davis, G.F. (2007). Organizations and organizing rational, natural and open systems perspectives. New Jersey: Upper Saddle River.

Scott, K.A. ve Zweig, D. (2008). Dispositional predictors of organizational cynicism. Administrative Sciences Association of Canada: 95-113.

Sekaran, U. (2003). Research methods for business: a skillbuilding approach. New York: John Wiley \& Sons.

Seligman, M.E.P. ve Csikszentmihalyi, M. (2000). Positive psychology: An introduction. American Psychologist, 55 (1), 5-14.

Seligman, M.E.P., Parks, A.C. ve Steen, T. (2004). A balanced psychology and a full life. The Royal Society, 359: 1379-1381.

Shabir, M., Abrar, M., Baig, S.A. ve Javed, M. (2014). The contribution of workplace incivility and psychological capital toward job stress. International Journal of Human Resource Studies, 4 (2), 1-17.

Shahnawaz, M.G. ve Jafri, M.H. (2009). Psychological capital as predictors of organizational commitment and organizational citizenship behavior. Journal of the Indian Academy of Applied Psychology, 35: 78-84.

Sheldon, M.E. (1971). Investments and involvements as mechanisms producing commitment to the organization. Administrative Science Quarterly, 16: 143-150.

Sheldon, K.M. ve King, L. (2001). Why positive psychology is necessary. American Psychologist, 56 (3), 216-217.

Sığrı, Ü. ve Basım, H.N. (2006), İş görenlerin iş doyumu ile örgütsel bağlılık düzeylerinin analizi: Kamu ve özel sektörde karşılaştırmalı bir araştırma. Selçuk Üniversitesi Sosyal ve Ekonomik Araştırmalar Dergisi, 6 (12), 131-154.

Stajkovic, A.D. ve Luthans, F. (1998). Self-efficacy and work-related task performance: A meta-analysis. Psychological Bulletin, 124 (2), 240-261.

Stanley, D.J., Meyer, J.P. ve Topolnytsky L. (2005). Employee cynicism and resistance to organizational change. Journal of Business and Psychology, 19 (4), 429-459.

Steers, R.M. (1981). Introduction to organizational behavior. Santa Monica-California: Oodyear Publishing Company Inc.

Tan, S.J. ve Tan, K.L. (2007). Antecedents and consequences of skepticism toward health claims: An empirical investigation of Singaporean consumers. Journal of Marketing Communications, 13 (1), 59-82.

Totawar, A.K. ve Nambudiri, R. (2014). How does organizational justice influence job satisfaction and organizational commitment? Explaining with psychological capital. Vikalpa: The Journal for Decision Makers, 39 (2), 83-97.
Turner, N., Barling, J. ve Zacharatos, A. (2002). Positive psychology at work. C.R. Snyder ve S.J. Lopez (Ed.), Handbook of positive psychology (s.715-728). New York: Oxford University Press.

Ugboro, I. ve Obeng, K. (2000). Top management leadership, employee empowerment, job satisfaction, and customer satisfaction in total quality management organizations: An empirical study. Journal of Quality Management, 5: 247-272.

Vazquez, C., Hervas, G., Rahona, J.J. ve Gomez, D. (2009). Psychological well-being and health: contributions of positive psychology. Annuary of Clinical and Health Psychology (APCS), 5: 15-27.

Vitell, S.J. ve Singhapakdi, A. (2008). The role of ethics institutionalization in influencing organizational commitment, job satisfaction and esprit de corps. Journal of Business Ethics, 81 (2), 343-353.

Vroom, V.H. (1964). Work and motivation. San Francisco, CA: Jossey-Bass.

Wanous, J.P., Reichers, A.E. ve Austin, J.T. (2000). Cynicism about organizational change: Measurement, antecedents, and correlates. Group and Organization Management, 25 (2), 132-53.

Wasti, S.A. (1999). A cultural analysis of organizational commitment and turnover intentions in a collectivist society. Academy of Management Proceedings: B1-B6.

Watson, D. (2002). Positive affectivity: The disposition to experience pleasurable emotional states. C.R. Snyder ve S.J. Lopez (Ed.), Handbook of positive psychology (s. 106-120). New York: Oxford University Press.

Wilkerson, J., Evans, W. ve Davis, W. (2008). A test of coworkers' influence on organizational cynicism, badmouthing, and organizational citizenship behavior. Journal of Applied Social Psychology, 38 (9), 22732292.

Wright, P.M., Dunford, B.B. ve Snell, S.A. (2001). Human resources and the resource based view. Journal of Management, 27: 701-721.

Wright, T.A. (2003), Positive organizational behavior: An idea whose time has truly come. Journal of Organizational Behavior, 24: 437-442.

Yoon, J. ve Thye, S. (2002). A dual process model of organizational commitment: Job satisfaction and organizational support. Work \& Occupations, 29 (1), 97-124.

Youssef, C.M. ve Luthans, F. (2007). Positive organizational behavior in the workplace: The impact of hope, optimism, and resilience. Journal of Management, 33 (5), 774-800.

Yousef, D.A. (1998). Satisfaction with job security as a predictor of organizational commitment and job performance in a multicultural environment. International Journal of Manpower, 19 (2), 184-194. 

